\title{
Evolution of Yoga and Physiotherapy
}

\author{
Madan Mohan Padhi* \\ Former Deputy Director General, Central Council for Research in Ayurvedic Sciences, India
}

Submission: October 06, 2016; Published: October 20, 2016

*Corresponding author: Madan Mohan Padhi, Former Deputy Director General, Central Council for Research in Ayurvedic Sciences, Ministry of AYUSH, Government of India, C4E/210, Janakpuri, New Delhi - 110058, India.

\section{Editorial}

Yoga has been originated in India by ancient sages. As per history of ancient India, those sages were living mostly sedentary life with limited scope of physical exercise since they were mostly engaged with ritual activities like Yajna, meditation etc. Their food items were also limited to vegetarian items especially edible raw roots, fruits, and leave etc. available in forest area. There were increasing urbanization and common men started establishing settlement and their food habits and lifestyle was different from sages.

All these led to occurrence of several diseases which they started coining with single term. In order to prevent and combat diseases, the sages made observations on diet, physical activities and other lifestyle factors in relation to diseases. Then they discovered the diseases alleviating properties of various plant products which resulted to scribing of medical science called Ayurveda. Simultaneously, since it was not possible for them to go for physical labour, they decided to innovate something which they can practice in house or without requiring a bigger space. They made observations on various aerobics, anaerobic, postural and breathing exercises, their specific effect on specific organ or whole body and mind also. They linked these procedures with regulated diet and other physical activities. They also linked with spirituality linking the composition and phenomena of human body with supreme soul, cosmos or the Universe.

A coordinated and synchronized performance of such practice is called Yoga which in Sanskrit language, literally means "to join with". The joining of soul with supreme soul is final stage of Yoga. This implies the belief in God; to live in peace and harmony eco-friendly environment, non-violence, no harm to others etc. which will not only render physical fitness or disease free life but also mental, social and spiritual well being.
While Punarvasu Atreya, Dhanvantari, Sushruta, Charaka, Vagbhata etc excelled in different disciplines of Ayurveda, Patanjali, Maharshi (around 2nd Century B.C.) has been told to be the first writer of Yogic principles and first propagator of Yoga. Since then, several books on Yoga have been scribed and modified Yoga has been propagated internationally by different scholars or groups.

Due to non-drug therapy, it can be practiced alone or as an adjuvant to any other system or therapy. Several research studies have also been reported regarding benefits of Yogic practice from reputed academic and research organization. Apart from research studies the practice of Yoga has been popularized among public in most parts of the World. The declaration of 21st June as International Day for Yoga by United Nations has reflected its acceptance and popularity. Still, more scientific studies are required to establish its benefits and for more acceptance among medical fraternity.

Similarly, though glimpses of Physiotherapy is believed to be practiced by the physicians around $460 \mathrm{BC}$ up to 19 th Century there was no much propagation like that of innovations in modern medical sciences. The documented origin of physiotherapy came by Swedish gymnast's professional group in 1813. In 1887, Physiotherapists were given official recognition. Since then, it spread to other countries and added with several natural processes, mechanical and electronic controlled process. Hence, both Yoga and Physiotherapy are beneficial along with naturopathy, Ayurveda, traditional or modern medicine.

The Journal of Yoga and Physiotherapy will be a landmark to gather review or original research articles which will be a broader platform to disseminate relevant information internationally. I wish grand success for launching of JYP. 


Your next submission with JuniperPublishers
will reach you the below assets
- Quality Editorial service
- Swift Peer Review
- Reprints availability
- E-prints Service
- Manuscript Podcast for convenient understanding
- Global attainment for your research
- Manuscript accessibility in different formats
( Pdf, E-pub, Full Text, Audio)
- Unceasing customer service
Track the below URL for one-step submission
http://juniperpublishers.com/online-submission.php

